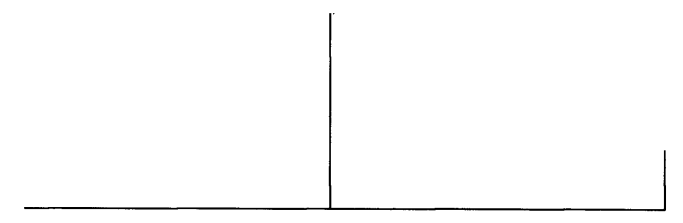

\title{
"Você pode viver com as vozes em sua cabeça"? De acordo com uma organização internacional de "ouvintes", a resposta é sim
}

\author{
Mônica Teixeira
}

O texto que publicamos nesta edição da Revista chamou a atenção dos editores por informar sobre a existência de uma organização, de origem européia, denominada "Hearing Voices Network" - Rede dos que ouvem vozes. Criada nos anos 1990, a rede está em 15 países; por iniciativa dela, pessoas que ouvem vozes se reúnem para conversar sobre a experiência - há 170 grupos só na Grã Bretanha. Para a HVN, o preceito fundamental é: vozes são para conviver e não para erradicar.

O artigo, de Daniel B. Smith, foi publicado no Magazine dominical do New York Times; e resulta do livro Muses, Madmen and Prophets - Rethinking the History, Science, and Meaning of Auditory Hallucination (Musas, loucos e profetas - Repensando a história, a ciência e o significado da alucinação auditiva), escrito por ele e publicado em 2007. Smith escreve como um jornalista. Em seu texto, registra conversas com pessoas que ouvem vozes, vocifera contra a psicanálise, mostra simpatia pela terapia cognitivocomportamental. O mérito do seu trabalho está em dar a 


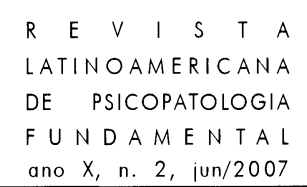

palavra à Rede dos que Ouvem Vozes - seus diretores, seus fundadores, gente que frequienta os grupos de auto-ajuda. Não mostra entusiasmo pela organização, mas ao mesmo tempo em que expõe as linhas fundamentais do pensamento que a anima, apresenta argumentos de psiquiatras de várias tendências, principalmente ingleses, sobre a psicose e sobre ouvir vozes.

No relato feito por Smith, a Rede dá testemunho da influência da antipsiquiatria na Grã Bretanha. A organização fala em "libertar" os que ouvem vozes; e um seu adepto classifica a luta por essa libertação como o último dos movimentos por direitos civis. Em completa oposição à psiquiatria, a HVN advoga o direito de cada um que ouve vozes a pensar o que quiser sobre elas. Também na contramão, o grupo recomenda atenção ao que dizem as vozes e sugere sua interpretação. Já o texto, para mostrar sua descrença, registra o desalento de quem ouve vozes frente à persistência delas e às "estratégias" recomendadas nas reuniões de grupo para lidar com elas. De tudo, fica um flagrante da vida contemporânea: o movimento de consumidores também chegou ao universo da psicose. 